\title{
The effect of 2 different premilking stimulation regimens, with and without manual forestripping, on teat tissue condition and milking performance in Holstein dairy cows milked 3 times daily
}

\author{
M. Wieland, ${ }^{1 *} \odot$ P. D. Virkler, ${ }^{1} \oplus$ A. Weld, ${ }^{2}$ J. M. Melvin, ${ }^{2} \odot$ M. R. Wettstein, ${ }^{2} \odot$ M. F. Oswald, ${ }^{2}$ C. M. Geary, ${ }^{1}$ \\ R. D. Watters, ${ }^{1}$ 이 R. Lynch, ${ }^{3}$ and D. V. Nydam ${ }^{1}$ () \\ ${ }^{1}$ Department of Population Medicine and Diagnostic Sciences, College of Veterinary Medicine, Cornell University, Ithaca, NY 14853 \\ ${ }^{2}$ College of Veterinary Medicine, Cornell University, Ithaca, NY 14853 \\ ${ }^{3}$ Department of Animal Science, College of Agriculture and Life Sciences, Cornell University, Ithaca, NY 14853
}

\begin{abstract}
The objectives were to study the effect of 2 different premilking stimulation regimens, with and without manual forestripping, on teat tissue condition and milking characteristics in dairy cows. In a randomized controlled crossover study, 130 Holstein cows milked 3 times daily were assigned to treatment and control groups. Premilking udder preparation for the treatment group consisted of: (1) predipping with 1\% iodine, (2) sequential forestripping of 3 streams of milk per quarter, (3) wiping of teats, and (4) attachment of the milking unit. Premilking udder preparation for the control group was identical except that the forestripping step was omitted. The mean tactile stimulation durations were $16 \mathrm{~s}$ and $7 \mathrm{~s}$ for the treatment and control group, respectively. The time spent from first tactile stimulus (either forestripping or wiping of teats) to milking unit attachment was kept consistent at $90 \mathrm{~s}$ for both groups. The study lasted for $14 \mathrm{~d}$ with 2 periods, each consisting of a 2 -d adjustment time followed by $5 \mathrm{~d}$ of data collection. Machine milking-induced short-term changes to the teat tissue were assessed by palpation and visually. The following milking characteristics were assessed with electronic on-farm milk meters: milk yield (MY), milking unit-on time (MUOT), 2-min MY (2MIN), and time spent in low milk flow rate (LMF). Generalized linear mixed models were used to describe the effect of treatment on the outcome variables. The odds of machine milking-induced short-term changes to the teat tissue were lower for cows that received forestripping compared with cows that were not forestripped (odds ratio $=0.31 ; 95 \%$ confidence interval $=0.22-0.42$ ) Least squares means (95\% confidence interval) for cows that were forestripped and animals that were not for-
\end{abstract}

Received March 17, 2020.

Accepted June 1, 2020.

*Corresponding author: mjw248@cornell.edu estripped, respectively, were $12.7(12.2-13.2)$ and 12.7 (12.2-13.2) $\mathrm{kg}$ for MY and 6.1 (5.8-6.4) and 5.6 (5.3$5.9) \mathrm{kg}$ for $2 \mathrm{MIN}$. There was an interaction between treatment and MY for LMF. Time spent in LMF for cows that were forestripped and received no forestripping, respectively, were 18 (17-20) and 24 (23-26) s for a MY level of $10 \mathrm{~kg}$; and $13(12-14)$ and $15(14-16)$ $\mathrm{s}$ for a MY level of $15 \mathrm{~kg}$. The effect of treatment on MUOT was modified by parity. Milking unit-on times for animals in first, second and third or greater lactation, respectively, were 230 (219-243), 249 (236-262), and 260 (249-272) s for cows that were forestripped, and 245 (232-258), 252 (239-266), and 268 (257-281) s for cows that received no forestripping. In this study, cows that were forestripped had shorter MUOT, higher 2MIN, lower LMF, and lower odds of exhibiting changes to the teat tissue after machine milking. We conclude that wiping of teats during premilking udder preparation alone and omitting forestripping of teats without compensating for the loss in stimulation time may not provide sufficient tactile stimulation to elicit the cows' maximum physiological milk-ejection capacity. This can aggravate the adverse effects of vacuum-induced forces on teat tissue during machine milking, diminish animal well-being, and possibly affect udder health.

Key words: milking characteristics, milking routine, oxytocin, premilking udder preparation

\section{INTRODUCTION}

The ultimate objective of premilking udder preparation is to facilitate harvesting high-quality milk from cows as gently, completely, and quickly as possible. In addition, it is valuable to monitor mammary health and thus, animal well-being. Current recommendations for premilking udder preparation include teat sanitization (i.e., premilking disinfection, cleaning, and drying of teats) and premilking stimulation (NMC, 2013). Premilking stimulation is composed of some 
form of tactile stimulus (i.e., manual or mechanical stimulation) and milking unit attachment timing (i.e., preparation lag time). It is essential for activating the milk-ejection reflex to harvest the alveolar milk, which represents approximately $80 \%$ of the udder's milk volume (Bruckmaier and Blum, 1996, 1998; Pfeilsticker et al., 1996). Manual forestripping (i.e., the removal of several streams of milk through manual compression of the teat; Wagner and Ruegg, 2002) is considered an effective stimulus to elicit the milk-ejection reflex and is therefore recommended as a means of premilking stimulation as well as detection of clinical mastitis (Rasmussen, 2000). Improper premilking stimulation reduces milk yield (MY) and milk flow (Bruckmaier et al., 1995; Bruckmaier and Hilger, 2001). Due to an inverse relationship between milk flow and vacuuminduced strain (Bade et al., 2009), improper stimulation aggravates the effect of machine milking on teat tissue condition. In a recent observational study, our group showed that a short preparation lag time was associated with higher odds of machine milking-induced teat tissue changes (Wieland et al., 2019). These shortterm changes have been associated with increased teat canal colonization (Zecconi et al., 1992), increased risk of new intramammary infection (Zecconi et al., 1996), and increased SCC (Zwertvaegher et al., 2013). In addition, short-term changes are considered to diminish animal well-being (Hillerton et al., 2002), which, along with the use of antimicrobials in food animals, is an increasing public concern. Most studies investigating premilking stimulation have concentrated on milking characteristics to improve parlor efficiency and profitability (Gorewit and Gassman, 1985; Smith et al., 2005; Weiss and Bruckmaier, 2005). By contrast, information on the relationship between premilking stimulation and teat tissue condition after milking is scarce and lacks a consensus (Hamann, 1992; Vetter et al., 2014).

A plethora of research has focused on improving genetic potential (Miglior et al., 2017) and increasing feed efficiency (Schwab and Broderick, 2017) to maximize milk production. By contrast, data on the most efficient milk harvesting process to fully benefit from recent accomplishments in animal genetics and nutrition are scarce. Specifically, there is a lack of information about the most efficient technique of premilking stimulation. In addition, most studies investigating the effect of premilking stimulation on milking performance have been performed in cows with a twice-daily milking schedule (Wagner and Ruegg, 2002; Weiss et al., 2003; Weiss and Bruckmaier, 2005; Kaskous and Bruckmaier, 2011; Edwards et al., 2013) or date back several decades (Sagi et al., 1980a, b; Gorewit and Gassman, 1985; Merrill et al., 1987; Rasmussen et al., 1990, 1992). Because results may no longer apply to high-producing dairy cows milked 3 times a day, no definite regimen has been recommended to dairy producers. Consequently, an increasing number of dairy producers reduce or eliminate the time spent on premilking stimulation (i.e., forestripping) in an attempt to increase parlor throughput and reduce labor costs (Durst et al., 2018). However, preliminary results from our own group, together with those from a recent observational study from Michigan (Erskine et al., 2019), suggest that insufficient premilking stimulation results in reduced milk production.

The primary objective of this study, therefore, was to investigate the effect of manual forestripping on machine milking-induced changes to teat tissue condition. We hypothesized that manual forestripping would reduce the adverse effects of machine milking to the teat tissue condition through improved activation of the milk-ejection reflex, shorter milking unit-on time (MUOT) at a higher milk flow rate yielding to less vacuum strain to the teat tissue. Our secondary objective was to study the effect of manual forestipping on milking performance. We hypothesized that forestripping would increase MY and milk flow rate and decrease MUOT.

\section{MATERIALS AND METHODS}

This randomized field trial was conducted at the Teaching Dairy Barn of the College of Veterinary Medicine, Cornell University (Ithaca, NY) from December 7 to 20, 2019. The study protocol was reviewed and approved by the Cornell University Institutional Animal Care and Use Committee (protocol no. 2019-0092).

\section{Animals and Housing}

The lactating herd consisted of approximately 160 Holstein cows. Cows were housed year-round in 2 freestall pens with sand bedding and fed a TMR that was formulated according to National Research Council requirements (NRC, 2001). The herd key performance indicators were average milk production, 12,282 kg; mean test day SCC, 254,000 cells/mL; monthly clinical mastitis incidence, $2.4 \%$; 21 -d pregnancy rate, $29.0 \%$; and culling risk, $37.9 \%$.

\section{Milking System}

Cows were milked 3 times/d at 0400, 1100, and 1900 $\mathrm{h}$ in a double-10 parallel milking parlor (P2100, DeLaval International AB, Tumba, Sweden). The vacuum pump $(7.5 \mathrm{~kW})$ was regulated by a variable frequency drive and set to supply a receiver operator vacuum of $45 \mathrm{kPa}$. The milking unit was composed of the cluster MC70 (weight: $2.1 \mathrm{~kg}$; DeLaval International AB) and 
a milking liner with a square barrel shape (ProSquare DPX2, IBA, Millbury, MA). The pulsators (Delatron, DeLaval International AB) were set to a pulsation rate of 60 cycles/min, a ratio of 70:30, and a side-to-side alternating pulsation. These settings resulted in pulsation phases of 125, a-phase; 573, b-phase; 105, c-phase; and $197 \mathrm{~ms}$, d-phase (values obtained with a digital vacuum recorder; VaDia, Biocontrol, Rakkestad, Norway). The average claw vacuum during the peak milk flow period as assessed with the VaDia device (Biocontrol) as the average cyclic vacuum fluctuations (assessed for 10 pulsation cycles $60 \mathrm{~s}$ after the start of the peak milk flow period) from 10 milking observations was $37.8 \mathrm{kPa}$. The automatic cluster removers were set to remove the units at a milk flow of $1.4 \mathrm{~kg} / \mathrm{min}$ with a 0 -s delay and a vacuum decay time of $2.3 \mathrm{~s}$. The milk sweep was initiated $1.5 \mathrm{~s}$ after unit retraction and lasted for $4 \mathrm{~s}$. The milk line was installed $75 \mathrm{~cm}$ below the cow standing level. All milking system settings were verified and assessed by the investigators according to the guidelines outlined by the National Mastitis Council (NMC, 2012) before the start of the study.

\section{Treatment Allocation}

Lactating cows were eligible for enrollment if they were free of clinical mastitis for at least $2 \mathrm{wk}$ and had no udder abnormalities such as nonlactating quarters or teat injuries. Eligible cows were randomly assigned to treatment and control groups stratified by parity, stage of lactation, and average daily MY during the previous week using a random number generator (Urbaniak and Plous, 2013). The milking routine was performed by 2 operators/milking session. During sessions 1 and 2, operators were 1 farm employee and the first author (MW) for all but 2 morning sessions (session 1), during which MW was replaced by another investigator (AW) to facilitate assessment of postmilking teat tissue condition. Milking session 3 was operated by students of the Cornell University College of Veterinary Medicine (Ithaca, NY). To facilitate compliance to the study protocol including adherence to the 90 -s preparation lag time, 2 investigators monitored the milking routine during each milking session and assisted with milking unit attachment as needed.

Premilking udder preparation for the treatment group was performed in sets of 5 cows in 4 steps and consisted of: step 1, predipping with 1\% iodine (Multi Dose MD; DeLaval International AB) using a teat dip applicator cup; step 2, sequential forestripping of 3 streams of milk per quarter; step 3, wiping (i.e., drying and cleaning) of teats with a clean cloth towel; and step 4 , attachment and alignment of the milking unit. Premilking udder preparation for the control group was identical except the forestripping step was not performed. The duration for manual forestripping and drying, respectively, was assessed from a haphazard sample of 99 and 154 milking observations. The average [mean $\pm \mathrm{SD}$, median (range)] durations were: forestripping, $8.6 \pm 5.0,7$ (3$31) \mathrm{s}$; and wiping of teats, $7.2 \pm 3.0,7(1-21) \mathrm{s}$. After milking unit detachment, all teats were dipped with $1 \%$ iodine (Multi Dose MD) using the same method as for predipping. The time spent from first tactile stimulus (either forestripping or wiping of teats) to milking unit attachment (i.e., preparation lag time) was kept consistent at $90 \mathrm{~s}$ for both treatments. To facilitate this, a timer $(99 \mathrm{M} / 59 \mathrm{~S}$ Timer, Traceable Products, Webster, TX) was installed at each stall and started at the time of the first forestrip or wipe, respectively.

In an effort to increase the sample size, this trial was designed as a crossover study. Thus, the first treatment period was $7 \mathrm{~d}$ long and consisted of $2 \mathrm{~d}$ of adjustment time followed by $5 \mathrm{~d}$ of data collection. On $\mathrm{d} 8$ of the study, cows were switched to the other treatment and followed for another $7 \mathrm{~d}$ ( $2 \mathrm{~d}$ of adjustment time, $5 \mathrm{~d}$ of data collection).

\section{Sample Size Calculation}

The sample size calculation was based on the primary outcome, the effect of treatment on presence of machine milking-induced short-term changes to the teat tissue condition, which has a documented prevalence of 29.7 to $57.8 \%$ at the cow level (Wieland et al., 2018, 2019). Using a prevalence of $30 \%$, an $\alpha$ level of 0.05 , a power of 0.95 , and the ability to detect a change in risk of $15 \%$, a sample size of 232 (116 per group) would be required. The calculated sample size was then inflated by a factor of 0.1 because of an assumed attrition rate of $10 \%$, resulting in a pre-exclusion sample size of 256 cows. This calculation was based on a presumed $\mathrm{R}^{2}$ of 0.1 and an equal sample proportion $\left(\mathrm{G}^{*}\right.$ Power version 3.1.9.2; Faul et al., 2007).

The resulting sample size of 256 cows was sufficient to detect a minimum difference of $1 \mathrm{~kg} /$ milking session between the 2 groups at an $\alpha$ level of 0.05 with a power of 0.89 . This calculation was based on a reported standard deviation of $3.4 \mathrm{~kg}$ (Wieland et al., 2017), a presumed correlation between measurements within a cow of 0.5 , a total of 15 milking observations, and a repeated measures ANOVA (G*Power version 3.1.9.2; Faul et al., 2007).

\section{Data Acquisition}

Cow Characteristics. Cow characteristics such as parity, DIM, and 305-d mature-equivalent milk production, were obtained from the dairy management 
Table 1. Definitions of milking characteristics recorded with the electronic on-farm milk meter (MM27BC, DeLaval International AB, Tumba, Sweden)

\begin{tabular}{lll}
\hline Milking characteristic & Abbreviation & Definition ${ }^{1}$ \\
\hline Milk yield $(\mathrm{kg})$ & MY & Yield of milk recorded from start of milking to detachment \\
First $15 \mathrm{~s}$ milk flow rate $(\mathrm{kg} / \mathrm{min})$ & $15 \mathrm{~S}$ & Milk flow rate recorded in the first 15 s after start of milking \\
$15-30 \mathrm{~s}$ milk flow rate $(\mathrm{kg} / \mathrm{min})$ & $30 \mathrm{~S}$ & Milk flow rate between 15 and $30 \mathrm{~s}$ after start of milking \\
$30-60 \mathrm{~s}$ milk flow rate $(\mathrm{kg} / \mathrm{min})$ & $60 \mathrm{~S}$ & Milk flow rate between 30 and $60 \mathrm{~s}$ after start of milking \\
$60-120 \mathrm{~s}$ milk flow rate $(\mathrm{kg} / \mathrm{min})$ & $120 \mathrm{~S}$ & Milk flow rate between 60 and $120 \mathrm{~s}$ after start of milking \\
Average milk flow rate $(\mathrm{kg} / \mathrm{min})$ & AMF & Total milk yield $/$ milking-unit-on time \\
Peak milk flow rate $(\mathrm{kg} / \mathrm{min})$ & PMF & Maximum milk flow rate reached during milking \\
2 min milk yield $(\mathrm{kg})$ & LMF & Milk yield harvested within the first 2 min after start of milking \\
Time in low milk flow rate $(\mathrm{s})$ & MUOT & Seconds below $1 \mathrm{~kg} /$ min milk flow rate \\
Milking-unit-on time $(\mathrm{s})$ & Time recorded from start of milking to unit detachment \\
\hline
\end{tabular}

${ }^{1}$ Start of milking: Start of milking procedure as recorded by the milking point controller induced by push of start button.

software program (DairyComp 305, Valley Agricultural Software, Tulare, CA).

Milking Characteristics. Milking characteristics [MY (kg), first $15 \mathrm{~s}$ milk flow rate $(\mathbf{1 5 S} ; \mathrm{kg} / \mathrm{min})$, 15-30 s milk flow rate $(\mathbf{3 0 S} ; \mathrm{kg} / \mathrm{min}), 30-60$ s milk flow rate $(\mathbf{6 0 S} ; \mathrm{kg} / \mathrm{min}), 60-120$ s milk flow rate $(\mathbf{1 2 0 S}$; $\mathrm{kg} / \mathrm{min})$, average milk flow rate $(\mathrm{kg} / \mathrm{min})$, peak milk flow rate $(\mathrm{kg} / \mathrm{min}), 2$ min milk yield (2MIN; $\mathrm{kg})$, time spent in low milk flow rate (LMF; s), and MUOT (s)] were assessed at each milking with electronic on-farm milk meters using near-infrared technology (MM27BC, DeLaval International AB; Table 1) and recorded using the dairy farm management software (DelPro, DeLaval International $\mathrm{AB}$ ). For subsequent analysis, a new categorical variable (i.e., bimodal milk flow) was created and defined as follows: a bimodal milk flow was present if any of the incremental milk flow rates $30 \mathrm{~S}, 60 \mathrm{~S}$ or $120 \mathrm{~S}$ were lower than any of the previous ones (15S, $30 \mathrm{~S}$, and $60 \mathrm{~S}$ ).

Milking Irregularities. Presence of a milking liner slip and a milking unit kick-off were monitored with the electronic on-farm milk meters in conjunction with the software program. The threshold limit for milking liner slip was set to 175 . Presence of milking unit reattachment, manual milking mode, and manual milking unit detachment was registered via the milking point controller (MPC680, DeLaval International AB) and also documented with the software program.

Teat Tissue Condition. The assessment of postmilking teat tissue condition was performed by 2 trained investigators ( $\mathrm{MW}$ and $\mathrm{CMG}$ ). Machine milking-induced short-term changes to the teat tissue condition (STC) were visually assessed during sessions 1 and 2 on the fifth and sixth day of each treatment period according to the scoring system described by Hillerton et al. (2000). Briefly, within $60 \mathrm{~s}$ after unit detachment the condition of the teat base was classified as no visible mark present (score 1), visible mark present (score 2), or significant swelling (score 3); evaluation of consistency of the teat end was scored as soft (score 1), firm (score 2), or wedging present (score 3). The presence of a STC was considered if the condition of the teat base score was 3 , or the consistency at the teat-end score was $\geq 2$ for 1 or more teats; STC were absent otherwise.

\section{Analytical Approach}

Data were maintained in an Excel spreadsheet (Microsoft Office Excel 2016; Microsoft Corp., Redmond, WA). Before statistical analyses, data were screened for missing and erroneous values. Cows that were diagnosed with mastitis or received a treatment resulting in milk withholding were removed from the study. Data from cows that were lost to follow-up were included in the analyses up until the day of diagnosis, day of treatment, dry day, or the point of removal from the herd. Statistical analyses were performed with the software package SAS (version 9.4, SAS Institute Inc., Cary, NC). Descriptive statistics were generated with PROC MEANS and PROC FREQ.

Baseline Characteristics. Chi-squared tests were generated with PROC FREQ for differences in parity and stage of lactation. Differences in SCC $\left(\log _{10}\right.$-transformed) and average daily MY during the previous week were assessed with Student's t-test using PROC TTEST.

Teat Tissue Condition. Data from 990 cow observations were obtained and used for the final analyses. To determine differences in STC between the treatments, a generalized linear mixed model with a logit link and a binomial distribution was fitted with PROC GLIMMIX. Three covariance structures (autoregressive order 1, compound symmetry, and variance components) were tested to model the covariance of repeated measurements between study periods, days, and milking sessions within a cow, and the one that resulted in the smallest pseudo-Akaike's information criterion was selected. Treatment and order of treatment allocation were entered into the model as a fixed effect. Parity 
(first, second, and third or greater lactation), stage of lactation $(\leq 100,101-200$, and $>200$ DIM), milking session (sessions 1 and 2), and MUOT (s) were considered as additional independent variables and screened for inclusion initially through the univariable analysis. All variables with a $P$-value $<0.20$ in this step were considered in the initial model. Collinearity among eligible variables was assessed by calculating Spearman correlation coefficients in PROC CORR. A coefficient of $>|0.50|$ was considered to indicate collinearity. No collinearity was observed. Manual backward elimination was used to reach the final model. Finally, the 2-way interactions between treatment and remaining variables were tested one at a time. Significance was declared at $P<0.05$.

Milking Characteristics. A total of 3,768 milking observations were obtained from the software program. A total of $73(1.9 \%)$ observations were excluded due to erroneous values, resulting in a total of 3,372 milking observations that were available for final analyses. Manual milking and manual detachment were documented in $2(0.05 \%)$ and $79(2.1 \%)$ cases, respectively.

To study the effect of treatment on milking characteristics (MY, MUOT, 2MIN, and LMF), 4 separate general linear mixed models were fitted with PROC MIXED. The following steps were consistent for all 4 models. To account for the clustering of milking observations within day, cow, and treatment period, a random effect for cow crossed with day and study period was included. Treatment and order of treatment application were forced into the model as a fixed effect. The following additional independent variables were considered and screened for inclusion into each model initially through univariable analysis: parity (first, second, and third or greater lactation), stage of lactation ( $\leq 100,101-200,>200$ DIM), and milking session (sessions 1, 2, and 3). For the dependent variables MUOT, $2 \mathrm{MIN}$, and LMF, MY ( $\mathrm{kg} /$ milking session) was also considered. All variables with a $P$-value $<0.20$ in this step were considered in the initial models. Collinearity among eligible variables was assessed by calculating Spearman correlation coefficients in PROC CORR. A coefficient of $>0.50$ was considered to indicate collinearity. No collinearity was observed. Manual backward elimination was performed until each of the variables had a $P$-value $<0.05$ to establish the final model for each dependent variable. Confounding was assessed by observing regression coefficient changes. Variables that modified regression coefficients by $>20 \%$ were considered confounding factors. No confounding was observed. Finally, 2-way interactions between treatment and remaining variables were tested and remained in the model if $P$-value $<0.05$. Tukey-Kramer's post hoc test was used to control for the experimental error rate.
For all final models, the assumptions of homoscedasticity and normality of residuals were assessed by the inspection of residual plots versus corresponding predicted values and the examination of quantile-quantile residual plots. To satisfy these assumptions, data of the dependent variables MUOT and LMF were log-transformed. The resulting least squares estimates (LSM) were consequently back transformed and presented as the geometric mean and $95 \%$ confidence interval (CI). To illustrate the interaction term between treatment and MY for LMF, LSM, and 95\% CI were computed for the lower $(10 \mathrm{~kg} /$ milking session) and upper quartiles (15 kg/milking session), respectively.

Bimodal Milk Flow and Milking Irregularities. To compare the effect of treatment on bimodal milk flow, milking liner slip, milking unit kick-off, and milking unit reattachment, 4 separate generalized linear mixed models with a logit link and a binomial distribution were generated with PROC GLIMMIX. The models were built in accordance with the procedure outlined above for the effect of treatment on STC with the following 2 exceptions. First, milking session had 3 levels (sessions 1, 2, and 3). Second, in addition to parity, stage of lactation, and milking session, MY (kg/ milking session) was considered as covariate.

\section{RESULTS}

\section{Description of Study Population}

A total of 130 cows were enrolled in the study. The average (mean $\pm \mathrm{SD}$ ) DIM at day of enrollment was $178 \pm 105$ ranging from 20 to 725 d. Parity was distributed as follows: $39(30.0 \%)$ were in first, 38 (29.2\%) were in second, and $53(40.8 \%)$ animals were in third or greater lactation (35 in third; 9 in fourth; 8 in fifth, and 1 in sixth lactation). The average (mean \pm SD) daily MY 1 wk before enrollment was $37.8 \pm 8.9$ and ranged from 16.3 to $60.0 \mathrm{~kg}$. The median $\mathrm{SCC}$ was 53,000 ranging from 7,000 to $5,453,000$ cells $/ \mathrm{mL}$. Table 2 depicts baseline characteristics for both treatment groups. During the study period, 3 cows were dried off, 3 cows were sold, 1 cow was diagnosed with mastitis, and 1 cow was treated for a trauma according to the dairy farms standard operating procedure. Thus, 122 cows completed crossover treatments.

\section{Teat Tissue Condition}

The presence of STC was recorded in 246 of 495 $(49.7 \%)$ and 379 of 495 (76.6\%) cow observations in cows that were forestripped and cows that received no forestripping, respectively. The final model for the presence or absence of STC is shown in Supplemental 
Table S1 (https://doi.org/10.3168/jds.2020-18551). The order of treatment application had no meaningful effect on STC $(P=0.54)$. The odds of STC were lower for cows that were forestripped compared with animals that received no forestripping [odds ratio $(\mathbf{O R})=0.31$; $95 \% \mathrm{CI}=0.22-0.42]$.

\section{Milking Characteristics}

The average [mean \pm SD (median; range)] MY, MUOT, 2MIN, and LMF during the study period were $12.7 \pm 3.9(12.3 ; 0.6-27.5) \mathrm{kg}, 261 \pm 76$ (248; 80-1,154) s, $5.9 \pm 2.1(6.0 ; 0-13.4) \mathrm{kg}$, and $25 \pm 40(13$; $0-636)$ s. Table 3 depicts descriptive statistics of milking characteristics stratified by treatments. The effect of forestripping on milking performance was evaluated based on the outcome variables MY, MUOT, 2MIN, and LMF. The results of general linear mixed models for each outcome variable are demonstrated in Supplemental Tables S2 to S5 (https://doi.org/10.3168/jds .2020-18551) and summarized in Figure 1. There was no meaningful effect of the order of treatment application on MY $(P=0.79)$, MUOT $(P=0.57)$, 2MIN $(P$ $=0.94)$, and $\operatorname{LMF}(P=0.54)$. Conversely, the order of treatment application had an effect on the presence or absence of bimodal milk flow $(P=0.03)$. We detected differences between treatments for 2MIN, MUOT, and LMF $(P<0.0001)$, whereas no meaningful differences were detected for MY $(P=0.76)$. Least squares means $(95 \% \mathrm{CI})$ for cows that were forestripped and animals that were not forestripped, respectively, were MY, 12.7 $(12.2-13.2)$ and $12.7(12.2-13.2) \mathrm{kg}$ and $2 \mathrm{MIN}, 6.1$
(5.8-6.4) and 5.6 (5.3-5.9) kg. There was an interaction between treatment and parity for MUOT $(P=0.03)$. The MUOTs in the first, second, and third or greater lactation animals, respectively, were 230 (219-243), 249 (236-262), and 260 (249-272) s for cows that were forestripped, and 245 (232-258), 252 (239-266), and 268 (257-281) s for cows that received no forestripping. Tukey-Kramer's post hoc test revealed differences between treatments in first-lactation animals $(P<$ 0.0001 ), whereas no statistically meaningful differences were observed for cows in second and third or greater lactation cows $(P \geq 0.07)$. We observed an interaction between treatment and MY for $\operatorname{LMF}(P<0.0001)$. Times spent in LMF for cows that were forestripped and those that received no forestripping, respectively, were $18(17-20)$ and $24(23-26)$ s for a MY of $10 \mathrm{~kg}$; and $13(12-14)$ and $15(14-16) \mathrm{s}$ for a MY of $15 \mathrm{~kg}$ and were different between treatments for both values of MY $(P<0.0001)$. Bimodal milk flow was documented in 1,396 of $3,732(37.4 \%)$ milking observations. The final generalized linear mixed model revealed differences between treatments for the presence or absence of a bimodal milk flow (Supplemental Table S6, https://doi .org/10.3168/jds.2020-18551; $P<0.0001)$. The odds of a bimodal milk flow were lower for cows that received forestripping compared with those that were not forestripped $(\mathrm{OR}=0.68 ; 95 \% \mathrm{CI}=0.57-0.81)$.

\section{Milking Irregularities}

Frequency distributions for milking irregularities were milking liner slip, 461/3,732 (12.4\%); milking unit kick-

Table 2. Baseline characteristics of 130 Holstein cows subjected to 2 different premilking stimulation regimens over a 14-d period

\begin{tabular}{|c|c|c|c|c|}
\hline \multirow[b]{2}{*}{ Item } & \multicolumn{2}{|c|}{ Treatment group $^{1}$} & \multirow[b]{2}{*}{ Overall } & \multirow[b]{2}{*}{$P$-value ${ }^{2}$} \\
\hline & A & $\mathrm{B}$ & & \\
\hline Parity (n, \%) & & & & 0.72 \\
\hline First & $21(32.31)$ & $18(27.69)$ & $39(30.00)$ & \\
\hline Second & $17(26.15)$ & $21(32.31)$ & $38(29.23)$ & \\
\hline Third or greater & $27(41.54)$ & $26(40.00)$ & $53(40.77)$ & \\
\hline Stage of lactation (n, \%) & & & & 0.24 \\
\hline$\leq 100$ DIM & $12(18.56)$ & $20(30.77)$ & $32(24.62)$ & \\
\hline 101-200 DIM & $27(41.54)$ & $21(32.31)$ & $48(36.92)$ & \\
\hline$>200$ DIM & $26(40.00)$ & $24(36.92)$ & $50(38.46)$ & \\
\hline $\operatorname{logSCC}($ mean $\pm \mathrm{SD})$ & $1.89 \pm 0.07$ & $1.78 \pm 0.07$ & $1.83 \pm 0.59$ & 0.26 \\
\hline Average milk yield ${ }^{4}(\mathrm{~kg}$, mean $\pm \mathrm{SD})$ & $37.4 \pm 9.2$ & $37.4 \pm 9.1$ & $37.4 \pm 9.1$ & 0.97 \\
\hline
\end{tabular}

${ }^{1}$ Cows in treatment group A received forestripping for $\mathrm{d}$ 1-7 and received no forestripping from d 8-14; cows in group B were not forestripped from d 1-7 and received forestripping from d 8-14. Days 1, 2, 8, and 9 were considered adjustment time and excluded from the analyses.

${ }^{2} P$-values derived from Pearson's chi-squared tests and Student's $t$-tests for categorical and continuous variables, respectively.

${ }^{3} \operatorname{logSCC}=$ SCC from previous test date, $\log _{10}$ transformed.

${ }^{4}$ Daily average milk yield for the last $7 \mathrm{~d}$ before enrollment. 
off, $160 / 3,732(4.2 \%)$; and milking unit reattachment, $223 / 3,732(6.0 \%)$. Table 3 depicts frequency distributions for milking irregularities stratified by treatment. Results of the final models for milking liner slips, milking unit kick-off, and milking unit reattachment are demonstrated in Supplemental Tables S7 to S9 (https: //doi.org/10.3168/jds.2020-18551). The order of treatment allocation had no meaningful effect on milking unit kick-off and milking unit reattachment $(P \geq 0.14)$, whereas the order of treatment allocation had an effect on the presence or absence of a milking liner slip $(P$ $=0.02)$. There was no association between treatment and milking liner slip $(P=0.08)$, milking unit kick-off $(P=0.14)$, and milking unit reattachment $(P=0.47)$. The OR (95\% CI) for cows that received forestripping compared with animals that were not forestripped, respectively, were milking liner slip, 1.25 (0.98-1.59); milking unit kick-off, 1.03 (0.69-1.53); and milking unit reattachment, $0.90(0.65-1.26)$.

\section{DISCUSSION}

\section{Teat Tissue Condition}

In this study, we investigated the effect of 2 different premilking stimulation regimens, with and without manual forestripping, on machine milking-induced changes to the teat tissue condition in high-producing Holstein dairy cows milked 3 times daily. Our data show that a regimen that is composed of forestripping and wiping of teats for a total duration of $16 \mathrm{~s}$ decreased the odds of STC compared with a regimen that consists of $7 \mathrm{~s}$ of wiping of teats. Machine milking-induced short-term changes have been associated with increased risk of new IMI (Zecconi et al., 1996) and reported to diminish animal well-being (Hillerton et al., 2002). Our results are thus of particular importance as they indicate an efficient measure to improve udder health and animal well-being.

We hypothesize that the decreased odds of STC in cows that received manual forestripping were related to the 4 following facts. First, MUOT in cows that were forestripped was shorter compared with cows that did not receive forestripping. This decreased the duration that teats were subjected to vacuum-induced strain causing congestion and edema of the teat tissue (Williams and Mein, 1982). Second, cows that were forestripped had higher milk flow rates and spent less time in LMF. Due to an inverse relationship between milk flow rate and vacuum-induced strain to the teat tissue (Bade et al., 2009; Ambord and Bruckmaier, 2010), this likely led to a lower magnitude of forces that create congestion and edema of the teat tissue. Third, cows that were forestripped were subjected to a longer duration of tactile stimulation. This may have resulted in higher oxytocin concentration and more efficient milk ejection into the gland and teat cistern thereby increasing the intracisternal pressure yielding to an increased teat diameter and better seal between the

Table 3. Descriptive statistics of milking characteristics and milking irregularities from 3,732 milking observations (group forestripping, 1,854; group no forestripping, 1,878) of 130 cows (crossed to 260 cows) subjected to 2 different premilking teat stimulation regimens over a period of $14 \mathrm{~d}$

Treatment

\begin{tabular}{|c|c|c|c|c|c|c|}
\hline Item & \multicolumn{3}{|c|}{ Forestripping } & \multicolumn{3}{|c|}{ No forestripping } \\
\hline $15 \mathrm{~S}(\mathrm{~kg} / \mathrm{min})$ & $0.50 \pm 0.36$ & 0.4 & $0-2.00$ & $0.46 \pm 0.35$ & 0.4 & $0-1.80$ \\
\hline $30 \mathrm{~S}(\mathrm{~kg} / \mathrm{min})$ & $2.81 \pm 1.14$ & 2.80 & $0-6.50$ & $2.57 \pm 1.12$ & 2.60 & $0-5.80$ \\
\hline $60 \mathrm{~S}(\mathrm{~kg} / \mathrm{min})$ & $3.22 \pm 1.38$ & 3.40 & $0-7.40$ & $2.74 \pm 1.41$ & 2.85 & $0-6.60$ \\
\hline $120 \mathrm{~S}(\mathrm{~kg} / \mathrm{min})$ & $3.72 \pm 1.24$ & 3.80 & $0-8.30$ & $3.50 \pm 1.34$ & 3.60 & $0-7.40$ \\
\hline $2 \mathrm{MIN}(\mathrm{kg})$ & $6.15 \pm 2.10$ & 6.30 & $0-13.4$ & $5.62 \pm 2.14$ & 5.62 & $0-12.32$ \\
\hline $\operatorname{LMF}(\mathrm{s})$ & $22 \pm 35$ & 12 & $0-626$ & $28 \pm 43$ & 14 & $0-636$ \\
\hline $\operatorname{MUOT}(\mathrm{s})$ & $257 \pm 77$ & 243 & $129-626$ & $265 \pm 75$ & 252 & $77-657$ \\
\hline $\operatorname{Bimodal}^{2}(\mathrm{n}, \%)$ & & $617(33.3)$ & & & $779(41.5)$ & \\
\hline Liner slip (n, \%) & & $255(13.8)$ & & & $206(11.0)$ & \\
\hline Kick-off $(n, \%)$ & & $82(4.4)$ & & & $78(4.2)$ & \\
\hline Reattach (n, \%) & & $105(5.7)$ & & & $118(6.3)$ & \\
\hline
\end{tabular}

${ }^{1}$ Days $1,2,8$, and 9 were considered adjustment time and excluded from the analyses. Data were obtained with electronic on-farm milk meters (MM27BC, DeLaval International AB, Tumba, Sweden). Results presented as mean \pm SD, median, and range unless otherwise stated. See Table 1 for abbreviation and definitions.

${ }^{2}$ Case definition for bimodal milk flow curve: If any of the incremental milk flow rates (30S, 60S, and $\left.120 \mathrm{~S}\right)$ were lower than any of the previous ones $(15 \mathrm{~S}, 30 \mathrm{~S}$, and $60 \mathrm{~S})$. 
A

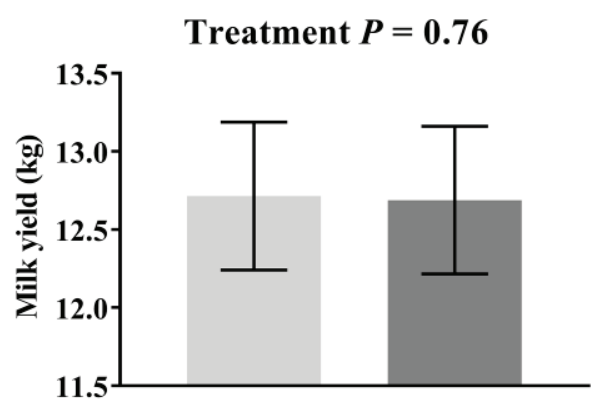

B

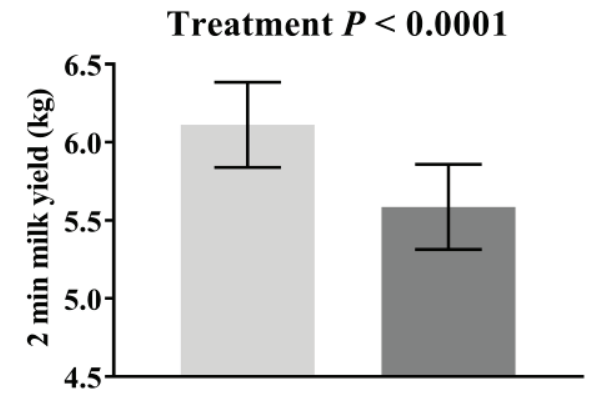

Forestripping

\section{C}

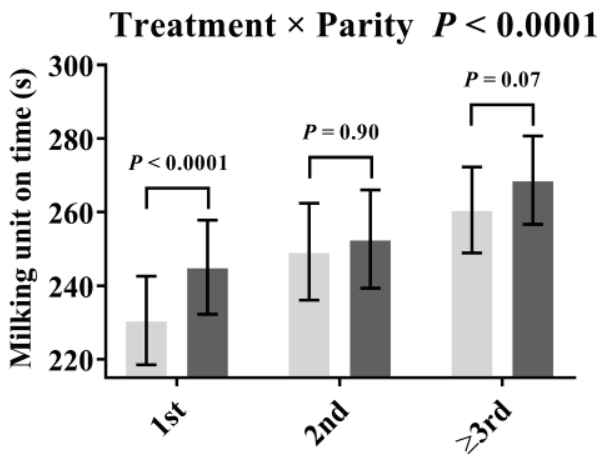

D

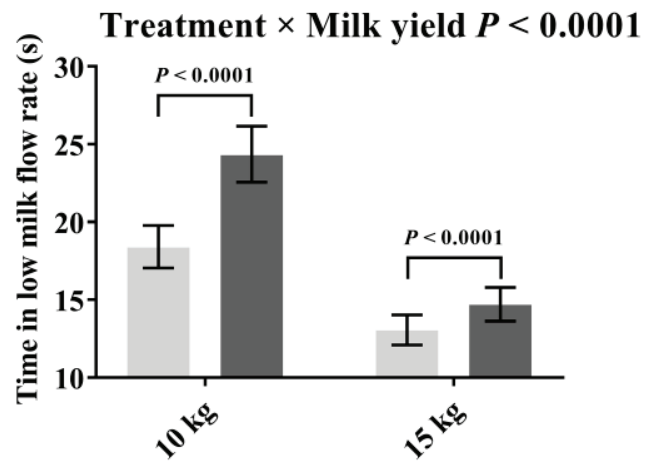

No Forestripping

Figure 1. Least squares means from general linear mixed models showing the effect of 2 different premilking stimulation regimens on (A) milk yield, (B) 2-min milk yield, (C) milking unit-on time, and (D) time spent in low milk flow rate. In (C), $P$-values for the effect of treatment between cows of different parity groups were derived from Tukey-Kramer's post hoc test. In (D), least squares means for the interaction between treatment and milk yield were calculated for the lower $(10 \mathrm{~kg})$ and upper $(15 \mathrm{~kg})$ quartiles. $P$-values for the effect of treatment between cows of different milk yields were derived from Tukey-Kramer's post hoc test. Error bars represent $95 \%$ CI. For results of other main effects, see Supplemental Tables S1-S4.

teat and the milking liner barrel. This could have led to a lower mouthpiece chamber vacuum (Borkhus and Rønningen, 2003), resulting in less teat congestion and edema, as suggested by Penry et al. (2017). Fourth, forestripped cows showed less bimodality which has been associated with increased mouthpiece chamber vacuum (Moore-Foster et al., 2019a). However, these possible explanations remain speculative as no measurements of oxytocin concentration, intracisternal pressure, or vacuum levels were obtained.

Our findings are consistent with those reported by Hamann (1992) who used 16 cows to study the effect of 3 different premilking stimulation treatments and 2 different milking liners on machine milking-induced changes in teat-end thickness. Cows received either no stimulation, $15 \mathrm{~s}$ of forestripping, or forestripping plus manual massage for $60 \mathrm{~s}$. The researcher found that the increase in teat-end thickness was largest for cows that received no premilking stimulation for both milking liners used (Hamann, 1992). Our results are in contrast with those reported by Vetter et al. (2014), who subjected 9 Holstein dairy cows to 2 different premilking udder preparation regimens combined with 2 different milking machine settings in a crossover study design. Premilking udder preparation consisted of either $45 \mathrm{~s}$ of continuous manual stimulation [i.e., forestripping of teats (4 streams of milk per teat) and udder cleaning for $15 \mathrm{~s}$ followed by $30 \mathrm{~s}$ of manual massage of teats and udder] or forestripping of teats and udder cleaning for $15 \mathrm{~s}$ followed by a $30 \mathrm{~s}$ latency period. The researchers evaluated the effect of treatment on teat tissue condition through quantification of dimensional changes of ultrasonographically assessed teat traits and found no statistical differences $(P \geq 0.19)$ between the 2 different premilking udder preparation regimens (Vetter et al., 2014). Discrepancies in study populations, milking routine (including milking frequencies and machine settings), and assessment technique could be variables that account for the differences observed between this study and the one described herein. 


\section{Milking Characteristics}

Our second objective was to study the effect of 2 different premilking stimulation regimens on milking characteristics. We found that cows that were forestripped had higher 2MIN, had lower LMF, and were less likely to exhibit bimodal milk letdown. In addition, cows in first lactation had shorter MUOT when they were forestripped, whereas no meaningful differences were detected for animals in second or third or greater lactation. By contrast, no meaningful differences in MY were detected between the 2 treatments. In the presence of a consistent preparation lag time, the observed differences are most likely due to the additional stimulatory effect of forestripping. The average duration of tactile stimulation in cows that received forestripping (i.e., time spent on forestripping and wiping) was $16 \mathrm{~s}$ compared with $7 \mathrm{~s}$ in cows that were not forestripped (i.e., time spent on wiping). The longer stimulation time likely resulted in an increased release of oxytocin from the posterior pituitary lobe into the blood circulation. This may have led to either increased stimulation of myoepithelial cells, stimulation of more myoepithelial cells, or both, which yielded to a stronger milk ejection from the alveolar cells into the duct system, thus increasing the amount of cisternal milk that was readily available for harvesting during the first minutes of milking. We conclude that drying and cleaning of teats for an average duration of $7 \mathrm{~s}$ with a cloth towel did not provide sufficient tactile stimulus to elicit the cows' maximum physiological milk-ejection capacity in this study population. Our results are consistent with current industry recommendations suggesting a minimum stimulation time of 10 to $20 \mathrm{~s}$ (Reneau and Chastain, 1995; Durst and Chojnacki, 2017; Wieland and Nydam, 2017), as well as recent research on premilking teat stimulation employing a minimum stimulation time of 15 s (Kaskous and Bruckmaier, 2011; Edwards et al., 2013; Vetter et al., 2014).

The absence of a treatment effect on MY is consistent with some studies (Sagi et al., 1980a, b; Merrill et al., 1987; Wagner and Ruegg, 2002; Kaskous and Bruckmaier, 2011; Edwards et al., 2013) but contrasts with results from previous work that found an effect of different premilking stimulation regimens on milk production (Rasmussen et al., 1992; Watters et al., 2015). Rasmussen et al. (1992) conducted 4 experiments using American Holstein ( $\mathrm{n}=12$, experiment $1 ; \mathrm{n}=8$, experiment 2), Danish Holstein $(\mathrm{n}=12$, experiment 3$)$, and Danish Jersey cows ( $\mathrm{n}=78$, experiment 4$)$. Cows were subjected to different durations of premilking teat preparation consisting of wiping of teats for 6 or 20 $\mathrm{s}$ combined with forestripping of 1 or 5 streams from each teat. Preparation lag times (i.e., time spent from first stimulus until milking unit attachment) differed between $0.5,1.3$, and $3 \mathrm{~min}$. The researchers found that longer teat stimulation increased MY for Danish Jersey cows, but not for Danish or American Holstein cows (Rasmussen et al., 1992).

In the New York State study, 30 Holstein cows were used to compare the effect of manual and mechanical teat stimulation on oxytocin release and milking characteristics. Treatments were randomly allocated in a crossover study design and consisted of (1) immediate milking unit attachment, (2) forestripping of 2 streams per teat and drying of teats with a preparation lag time of $30 \mathrm{~s}$, (3) forestripping and drying of teats with a preparation lag time of $90 \mathrm{~s}$, (4) immediate milking unit attachment followed by $30 \mathrm{~s}$ of mechanical stimulation, and (5) immediate milking unit attachment with 90 $\mathrm{s}$ of mechanical stimulation. The authors documented higher MY per milking session for cows that received no premilking stimulation and those who received $30 \mathrm{~s}$ of mechanical stimulation (Watters et al., 2015).

Differences in MUOT between treatment groups were also observed by previous investigators studying the effect of different premilking stimulation regimens on milking characteristics (Gorewit and Gassman, 1985; Merrill et al., 1987; Edwards et al., 2013). Our results are in contrast to those reported by others (Wagner and Ruegg, 2002; Vetter et al., 2014; Moore-Foster et al., 2019a), as well as findings from an observational study of our own group that indicated no association between premilking teat stimulation and MUOT (Wieland et al., 2019). In the Wisconsin study (Wagner and Ruegg, 2002), the researchers used 24 Holstein dairy cows to investigate the effect of manual forestripping on milking performance in a randomized trial. Cows in the treatment group received forestripping (3 streams of milk per teat), whereas control cows were not forestripped. The preparation lag time ranged between 60 and $80 \mathrm{~s}$. The authors found no significant differences in MUOT between treatment and control groups (Wagner and Ruegg, 2002). The research group of a recent study investigating herd-level variables that were associated with delayed milk ejection in 64 Michigan dairy herds found no association between milk letdown time (presumptively from inadequate stimulation) and MUOT (Moore-Foster et al., 2019a). The researchers suggested that, under certain circumstances (i.e., delayed milk ejection led to increased mouthpiece chamber vacuum, decreased teat canal diameter, and lower milk flow), cows might have been unable to milk effectively and failed to completely release their milk during milking resulting in decreased milk harvest. This possible explanation has been further supported by results from 
Erskine et al. (2019) who studied the relationship between delayed milk ejection and MY using the same diagnostic device and case definitions as Moore-Foster et al. (2019a) and found that MY decreased with increasing letdown time; a finding that is in contrast to our results. Differences in study population, premilking stimulation regimens, assessment techniques, and case definitions could be variables that help explain the discrepancies between these previous studies and the current one.

An effect of premilking teat stimulation on $2 \mathrm{MIN}$ has been reported previously (Schukken et al., 2005; Watters et al., 2012). Schukken et al. (2005) performed a field study on 4 New York dairy farms. A total of 705 cow milking observations were randomly allocated to 1 of 4 different treatments of premilking teat stimulation. Treatments consisted of (1) no forestripping, (2) forestripping of 3 streams of milk from 1 teat, (3) forestripping of 3 streams of milk from each of the 4 teats, and (4) forestripping of 12 streams of milk from 1 teat. All cows were dipped or sprayed with a teat disinfectant, teats were wiped approximately $60 \mathrm{~s}$ after application, and milking unit attachment occurred approximately $90 \mathrm{~s}$ after application of the teat disinfectant. The researchers found higher $2 \mathrm{MIN}$ in all cows that received some form of forestripping compared with cows that were not forestripped (Schukken et al., 2005).

In this study, cows that received forestripping had lower LMF. We believe that the difference can be attributed mostly to a difference in LMF at the beginning of the milking observation. That is, in the presence of a cluster remover take-off milk threshold of $>1 \mathrm{~kg} /$ min, the vast majority of LMF is accumulated at the beginning of the milking observation, for example, as a consequence of delayed milk ejection or a bimodal milk letdown. Our theory is further supported by the observed differences in bimodality between the treatments.

The odds of bimodality were lower in cows that received forestripping, which is similar to findings of previous works (Bruckmaier et al., 1995; Bruckmaier and Blum, 1996; Watters et al., 2012). Moore-Foster et al. (2019a) found that the proportion of cows in a herd with bimodality was negatively associated with mean total time of tactile stimulation, which is consistent with our findings. Some mention should be made of the case definition for bimodality in our study. Although we found differences between treatments, the biological relevance of the employed case definition has yet to be proven. Our case definition was rather sensitive yielding to a relatively high proportion of bimodality compared with, for example Moore-Foster et al. (2019a) who documented delayed milk ejection in an average of $25 \%$ of the cows in each of the 64 herds.

\section{Milking Irregularities}

An extension of our secondary objective was to assess the effect of treatments on milking irregularities. Milking liner slips and milking unit kick-offs interfere with the milking routine such that they distract milking technicians from their ongoing tasks. Monitoring of milking irregularities is therefore of paramount importance to achieve good parlor performance (Stewart et al., 2001). We appended these analyses due to our subjective observations during the study that cows that were not forestripped showed more restless behavior during milking. Our results do not support a measurable difference between the 2 treatments.

\section{Study Limitations and Future Directions}

Although we intended to best represent current milking practices on modern dairy operations with a thrice daily milking schedule, our study had some limitations that must be considered. First, we conducted our study on 1 New York dairy farm with Holstein cows that were milked 3 times/day. Our results are therefore likely to reflect what would happen in a commercial operation in this region. However, the generalizability of our study may be limited to similar operations employing a similar milking routine. Second, the study period was limited to $14 \mathrm{~d}$, and no udder health parameters were considered. Although we failed to identify differences in milk production, future studies investigating the effect of different premilking teat stimulation regimens on milk production and udder health over a whole lactation period are warranted to facilitate interference of its effect on these economically important variables. Third, cows that received no forestripping were identified with leg bands. Our reasoning was that we wanted to facilitate treatment application, thereby decreasing inadvertent variability. Consequently, we were not blinded to treatment during assessment of STC which may have led to information bias. However, most of our outcome variables were objectively measured by mechanical means not influenced by observer bias.

Last, we randomly allocated cows into treatment groups resulting in cows of both groups being milked at the same time. Consequently, parlor efficiency metrics were not assessed for obvious reasons. Albeit, our results suggest that forestripping in addition to wiping may result in increased parlor efficiency. For example, in our study, forestripping first-lactation animals yielded to an average time saving of $15 \mathrm{~s}$ per milking observation. Conversely, in the presence of consistent preparation lag time (i.e., $90 \mathrm{~s}$ ), elimination of the forestripping step does not result in gain of time. Because, in a parallel or herringbone parlor, the last or slowest 
milking cow in a row determines the row time, forestripping first-lactation animals in addition to wiping may therefore yield to time saving of $15 \mathrm{~s}$ per parlor turn. However, keeping preparation lag time consistent at $90 \mathrm{~s}$ is unlikely to happen on a commercial dairy farm that eliminates the forestripping step in an attempt to increase parlor throughput. That is, eliminating the forestripping step in the absence of additional changes to the milking routine will result in a decrease of the preparation lag time, in which case we expect an even larger effect on teat tissue condition and milking characteristics.

According to a recent observational study investigating herd-level variables associated with premilking stimulation time in 64 Michigan dairy herds, $25 \%$ of herds stimulated teats $<7.8 \mathrm{~s}$ during the initial tactile visit (tactile stimulation $=$ forestripping, wiping, and drying of teats, or application of automated teat brush) with a minimum stimulation time of $2.4 \mathrm{~s}$ (MooreFoster et al., 2019b). Future research should therefore investigate and identify opportunities to accommodate the physiological requirements of cows and enhance parlor efficiency. This could be accomplished through a combination of manual stimulation and automated stimulation features using inherent systems such as the pulsator system.

\section{CONCLUSIONS}

Cows that received no forestripping during premilking udder preparation had longer MUOT and spent more time below $1 \mathrm{~kg} / \mathrm{min}$ milk flow rate to harvest the same amount of milk per milking session. This likely enhanced the adverse effects of vacuum-induced strain to the teat resulting in increased odds of machine milking-induced teat tissue changes. We conclude that mere wiping of teats with a cloth towel for approximately $7 \mathrm{~s}$ during premilking udder preparation does not provide sufficient tactile stimulation to elicit the cows' maximum physiological milk-ejection capacity as compared with $16 \mathrm{~s}$ of stimulation that includes forestripping. This can aggravate the negative effects of mechanical forces on the teat tissue during machine milking, diminish animal well-being, and possibly affect udder health.

\section{ACKNOWLEDGMENTS}

The authors thank Blake Nguyen (Cornell University, Ithaca, NY) and the staff at the Cornell Teaching Dairy Barn (Ithaca, NY) for their willingness to participate in the study and their continued support during the trial. We also thank Belinda Gross (Ithaca, NY) for her invaluable assistance with records management. The authors acknowledge the students of the Cornell University College of Veterinary Medicine for their interest in the study and their willingness to accommodate the modified milking routine. This work was supported by the USDA National Institute of Food and Agriculture, Hatch project (grant number: 2019-20-243). Any opinions, findings, conclusions, or recommendations expressed in this publication are those of the author(s) and do not necessarily reflect the view of the National Institute of Food and Agriculture (NIFA) or the USDA. The authors have not stated any conflicts of interest.

\section{REFERENCES}

Ambord, S., and R. M. Bruckmaier. 2010. Milk flow-dependent vacuum loss in high-line milking systems: effects on milking characteristics and teat tissue condition. J. Dairy Sci. 93:3588-3594. https: //doi.org/10.3168/jds.2010-3059.

Bade, R. D., D. J. Reinemann, M. Zucali, P. L. Ruegg, and P. D. Thompson. 2009. Interactions of vacuum, b-phase duration, and liner compression on milk flow rates in dairy cows. J. Dairy Sci. 92:913-921. https://doi.org/10.3168/jds.2008-1180.

Borkhus, M., and O. Rønningen. 2003. Factors affecting mouthpiece chamber vacuum in machine milking. J. Dairy Res. 70:283-288. https://doi.org/10.1017/S0022029903006253.

Bruckmaier, R. M., and J. W. Blum. 1996. Simultaneous recording of oxytocin release, milk ejection and milk flow during milking of dairy cows with and without prestimulation. J. Dairy Res. 63:201208. https://doi.org/10.1017/S0022029900031708.

Bruckmaier, R. M., and J. W. Blum. 1998. Oxytocin release and milk removal in ruminants. J. Dairy Sci. 81:939-949. https://doi.org/10 $.3168 /$ jds.S0022-0302(98)75654-1.

Bruckmaier, R. M., and M. Hilger. 2001. Milk ejection in dairy cows at different degrees of udder filling. J. Dairy Res. 68:369-376. https:/ /doi.org/10.1017/S0022029901005015.

Bruckmaier, R. M., E. Rothenanger, and J. W. Blum. 1995. Milking characteristics in dairy cows of different breeds from different farms and during the course of lactation. J. Anim. Breed. Genet. 112:293-302. https://doi.org/10.1111/j.1439-0388.1995.tb00569.x.

Durst, P. T., and R. Chojnacki. 2017. How is variability in your farm's milking procedure affecting milk flow? Michigan State University Extension. Accessed Feb. 8, 2020. https://www.canr.msu .edu/news/how_is_variability_in_your_farms_milking_procedure _affecting_milk_flow.

Durst, P. T., S. J. Moore, C. Ritter, and H. W. Barkema. 2018. Evaluation by employees of employee management on large US dairy farms. J. Dairy Sci. 101:7450-7462. https://doi.org/10.3168/jds .2018-14592.

Edwards, J. P., J. G. Jago, and N. Lopez-Villalobos. 2013. Shortterm application of prestimulation and increased automatic cluster remover threshold affect milking characteristics of grazing dairy cows in late lactation. J. Dairy Sci. 96:1886-1893. https://doi.org/ 10.3168/jds.2012-6191.

Erskine, R. J., B. Norby, L. M. Neuder, and R. S. Thomson. 2019. Decreased milk yield is associated with delayed milk ejection. J. Dairy Sci. 102:6477-6484. https://doi.org/10.3168/jds.2018-16219.

Faul, F., E. Erdfelder, A. G. Lang, and A. Buchner. 2007. G*Power 3: A flexible statistical power analysis program for the social, behavioral, and biomedical sciences. Behav. Res. Methods 39:175-191. https://doi.org/10.3758/BF03193146.

Gorewit, R. C., and K. B. Gassman. 1985. Effects of duration of udder stimulation on milking dynamics and oxytocin release. J. Dairy Sci. 68:1813-1818. https://doi.org/10.3168/jds.S0022 -0302(85)81031-6.

Hamann, J. 1992. Physio-pathological aspects of machine milking. Pages 53-67 in Proc. International Symposium on Bovine Mastitis, Milan, Italy. Consiglio Nazionale delle Ricerche, Rome, Italy. 
Hillerton, J. E., I. Ohnstad, J. R. Baines, and K. A. Leach. 2000. Changes in cow teat tissue created by two types of milking cluster. J. Dairy Res. 67:309-317. https://doi.org/10.1017/ S0022029900004283.

Hillerton, J. E., J. W. Pankey, and P. Pankey. 2002. Effect of overmilking on teat condition. J. Dairy Res. 69:81-84. https://doi.org/ $10.1017 /$ S0022029901005386.

Kaskous, S., and R. M. Bruckmaier. 2011. Best combination of prestimulation and latency period duration before cluster attachment for efficient oxytocin release and milk ejection in cows with low to high udder-filling levels. J. Dairy Res. 78:97-104. https://doi.org/ 10.1017/S0022029910000816.

Merrill, W. G., R. Sagi, L. G. Petersson, T. V. Bui, H. N. Erb, D. M. Galton, and R. Gates. 1987. Effects of premilking stimulation on complete lactation milk yield and milking performance. J. Dairy Sci. 70:1676-1684. https://doi.org/10.3168/jds.S0022 -0302(87)80196-0.

Miglior, F., A. Fleming, F. Malchiodi, L. F. Brito, P. Martin, and C. F. Baes. 2017. A 100-Year Review: Identification and genetic selection of economically important traits in dairy cattle. J. Dairy Sci. 100:10251-10271. https://doi.org/10.3168/jds.2017-12968.

Moore-Foster, R., B. Norby, R. L. Schewe, R. Thomson, P. C. Bartlett, and R. J. Erskine. 2019a. Herd-level variables associated with delayed milk ejection in Michigan dairy herds. J. Dairy Sci. 102:696705. https://doi.org/10.3168/jds.2018-14561.

Moore-Foster, R., B. Norby, R. L. Schewe, R. Thomson, P. C. Bartlett, and R. J. Erskine. 2019b. Herd-level variables associated with premilking stimulation time in Michigan dairy herds. J. Dairy Sci. 102:2544-2550. https://doi.org/10.3168/jds.2018-14943.

NMC (National Mastitis Council). 2012. Procedures for Evaluating Vacuum Levels and Air Flow in Milking Systems. National Mastitis Council, Verona, WI.

NMC. 2013. Recommended milking procedures. Accessed March 16, 2020. http://www.nmconline.org/wp-content/uploads/2016/09/ Recommended-Milking-Procedures.pdf.

NRC (National Research Council). 2001. Nutrient Requirements of Dairy Cattle. 7th rev. ed. National Academies Press, Washington, DC.

Penry, J. F., J. Upton, G. A. Mein, M. D. Rasmussen, I. Ohnstad, P. D. Thompson, and D. J. Reinemann. 2017. Estimating teat canal cross-sectional area to determine the effects of teat-end and mouthpiece chamber vacuum on teat congestion. J. Dairy Sci. 100:821-827. https://doi.org/10.3168/jds.2016-11533.

Pfeilsticker, H. U., R. M. Bruckmaier, and J. W. Blum. 1996. Cisternal milk in the dairy cow during lactation and after preceding teat stimulation. J. Dairy Res. 63:509-515. https://doi.org/10.1017/ S0022029900032040.

Rasmussen, M. D. 2000. A review of milking preparation: The science. Pages 104-110 in Proceedings of the National Mastitis Council $39^{\text {th }}$ Annual Meeting. National Mastitis Council Inc., Madison, WI.

Rasmussen, M. D., E. S. Frimer, D. M. Galton, and L. G. Petersson. 1992. The influence of premilking teat preparation and attachment delay on milk yield and milking performance. J. Dairy Sci. 75:2131-2141. https://doi.org/10.3168/jds.S0022-0302(92)77973 -9 .

Rasmussen, M. D., E. S. Frimer, Z. Horvath, and N. E. Jensen. 1990. Comparison of a standardized and variable milking routine. J. Dairy Sci. 73:3472-3480. https://doi.org/10.3168/jds.S0022 -0302(90)79046-7.

Reneau, J. K., and J. P. Chastain. 1995. Premilking cow prep: Adapting to your system. Pages 46-63 in Proceedings of the National Mastitis Council $34^{\text {th }}$ Annual Meeting, Harrisburg, PA. National Mastitis Council Inc., Madison, WI.

Sagi, R., R. C. Gorewit, W. G. Merrill, and D. B. Wilson. 1980a. Premilking stimulation effects on milking performance and oxytocin and prolactin release in cows. J. Dairy Sci. 63:800-806. https://doi .org/10.3168/jds.S0022-0302(80)83009-8.

Sagi, R., R. C. Gorewit, and S. A. Zinn. 1980b. Milk ejection in cows mechanically stimulated during late lactation. J. Dairy Sci. 63:1957-1960. https://doi.org/10.3168/jds.S0022-0302(80)83165 -1 .
Schukken, Y. H., L. G. Petersson, D. V. Nydam, D. E. Baker, and FAME team. 2005. Using milk flow curves to evaluate milking procedures and milk equipment in Proceedings of the National Mastitis Council 44 ${ }^{\text {th }}$ Annual Meeting. National Mastitis Council Inc., Madison, WI.

Schwab, C. G., and G. A. Broderick. 2017. A 100-Year Review: Protein and amino acid nutrition in dairy cows. J. Dairy Sci. 100:1009410112. https://doi.org/10.3168/jds.2017-13320.

Smith, J. F., K. C. Dhuyvetter, M. J. VanBaale, D. V. Armstrong, and J. Harner. 2005. Managing the milking parlor: An economic consideration of profitability. Pages 165-180 in Proceedings of the National Mastitis Council $44^{\text {th }}$ Annual Meeting. National Mastitis Council Inc., Madison, WI.

Stewart, S., S. Eicker, and P. Rapnicki. 2001. Automated collection of parlor performance data: Information needed and proposed standardized definitions. Pages 377-381 in Proc. 2nd International Symposium on Mastitis and Milk Quality. National Mastitis Council and American Association of Bovine Practitioners, Madison, WI.

Urbaniak, G. C., and S. Plous. 2013. Research Randomizer (Version 4.0) Accessed on Dec. 6, 2019. http://www.randomizer.org/.

Vetter, A., H. A. van Dorland, M. Youssef, and R. M. Bruckmaier. 2014. Effects of a latency period between pre-stimulation and teat cup attachment and periodic vacuum reduction on milking characteristics and teat condition in dairy cows. J. Dairy Res. 81:107112. https://doi.org/10.1017/S0022029913000617.

Wagner, A. M., and P. L. Ruegg. 2002. The effect of manual forestripping on milking performance of Holstein dairy cows. J. Dairy Sci. 85:804-809. https://doi.org/10.3168/jds.S0022-0302(02)74139-8.

Watters, R. D., R. M. Bruckmaier, H. M. Crawford, N. Schuring, Y. H. Schukken, and D. M. Galton. 2015. The effect of manual and mechanical stimulation on oxytocin release and milking characteristics in Holstein cows milked 3 times daily. J. Dairy Sci 98:1721-1729. https://doi.org/10.3168/jds.2014-8335.

Watters, R. D., N. Schuring, H. N. Erb, Y. H. Schukken, and D. M. Galton. 2012. The effect of premilking udder preparation on Holstein cows milked 3 times daily. J. Dairy Sci. 95:1170-1176. https: //doi.org/10.3168/jds.2011-4388.

Weiss, D., and R. M. Bruckmaier. 2005. Optimization of individual prestimulation in dairy cows. J. Dairy Sci. 88:137-147. https://doi .org/10.3168/jds.S0022-0302(05)72671-0.

Weiss, D., A. Dzidic, and R. M. Bruckmaier. 2003. Effect of stimulation intensity on oxytocin release before, during and after machine milking. J. Dairy Res. 70:349-354. https://doi.org/10.1017/ S0022029903006216. https://doi.org/10.1017/S0022029903006216.

Wieland, M., J. M. Melvin, D. V. Nydam, and P. D. Virkler. 2019. A longitudinal prospective cohort study investigating the association of premilking stimulation and teat-end shape on milking characteristics and teat tissue condition in dairy cows. BMC Vet. Res. 15:58. https://doi.org/10.1186/s12917-019-1803-2.

Wieland, M. and D. V. Nydam. 2017. You have to go slow to go fast when milking cows. Hoard's Dairyman. 162:718.

Wieland, M., D. V. Nydam, N. Älveby, P. Wood, and P. D. Virkler. 2018. Short communication: Teat-end shape and udder-level milking characteristics and their associations with machine milkinginduced changes in teat tissue condition. J. Dairy Sci. 101:1144711454. https://doi.org/10.3168/jds.2018-15057.

Wieland, M., D. V. Nydam, and P. D. Virkler. 2017. A longitudinal field study investigating the association between teat-end shape and two minute milk yield, milking unit-on time, and time in low flow rate. Liv. Sci. 205:88-97. https://doi.org/10.1016/j.livsci.2017 .09 .011 .

Williams, D. M., and G. A. Mein. 1982. Review: Physical and physiological factors affecting milk flow rate from the bovine teat during machine milking. Pages $42-74$ in Proc. Conference on Dairy Production from Pasture. Hamilton, New Zealand.

Zecconi, A., V. Bronzo, R. Piccinini, P. Moroni, and G. Ruffo. 1996. Field study on the relationship between teat thickness changes and intramammary infections. J. Dairy Res. 63:361-368. https://doi .org/10.1017/S0022029900031885. 
Zecconi, A., J. Hamann, V. Bronzo, and G. Ruffo. 1992. Machineinduced teat tissue reactions and infection risk in a dairy herd free from contagious mastitis pathogens. J. Dairy Res. 59:265-271. https://doi.org/10.1017/S0022029900030545.

Zwertvaegher, I., S. De Vliegher, B. Verbist, A. Van Nuffel, J. Baert, and S. Van Weyenberg. 2013. Short communication: Associations between teat dimensions and milking-induced changes in teat dimensions and quarter milk somatic cell counts in dairy cows. J. Dairy Sci. 96:1075-1080. https://doi.org/10.3168/jds.2012-5636.

\section{ORCIDS}

M. Wieland ๑ https://orcid.org/0000-0003-0513-1782

P. D. Virkler ๑ https://orcid.org/0000-0002-9177-4663

J. M. Melvin ( https://orcid.org/0000-0001-5148-0137

M. R. Wettstein (1) https://orcid.org/0000-0001-5035-5457

R. D. Watters $($ ๑) https://orcid.org/0000-0002-7714-5887

D. V. Nydam (ㄴ) https://orcid.org/0000-0001-7717-4859 